University of Warwick institutional repository: http://go.warwick.ac.uk/wrap

This paper is made available online in accordance with publisher policies. Please scroll down to view the document itself. Please refer to the repository record for this item and our policy information available from the repository home page for further information.

To see the final version of this paper please visit the publisher's website. Access to the published version may require a subscription.

Author(s): Fuller, S.

Article Title: Why does history matter to the Science Studies disciplines? A case for giving the past back its future

Year of publication: 2011

Link to published article : http://dx.doi.org/10.1163/187226311X599952

Publisher statement: First published in the Journal of the Philosophy of History. Fuller, S. (2011). Why does history matter to the Science Studies disciplines? A case for giving the past back its future. Journal of the Philosophy of History, 5(3), pp. 562-585. 


\section{WHY DOES HISTORY MATTER TO THE SCIENCE STUDIES DISCIPLINES? A CASE FOR GIVING THE PAST BACK ITS FUTURE Steve Fuller}

Anyone who doubts the problematic nature of the disciplinary boundary separating history and philosophy should consider the chequered reputations of Hegel and Comte, neither of whom recognised a clear boundary. Science and technology studies (STS) provides yet more challenges to that boundary today, a radical version of which will be explored in this essay. STS is normally associated with 'social constructivism', which when applied to history of science highlights the malleability of the modal structure of reality. Specifically, changes to what is (e.g. by the addition or removal of ideas or things) implies changes to what has been, can be and might be. After exploring this point, most notably with regard to Latour's account of Pasteur's scientific achievement, I identify two polar attitudes towards the world's modal malleability: over- and under- determination, which correspond, respectively, to a belief in the inevitability and the precariousness of science as a form of knowledge, which I illustrate in terms of Popper's and MacIntyre's contrasting visions of a posthuman world. The distinctness of the two positions is an artefact of the cordon sanitaire that exists between the history and the philosophy of science, which is made at the cost of not giving historical figures full voice as constructors of reality: They are either quarantined to a foreign realm called 'the past' by the historian or selectively assimilated to an imperial present by the philosopher. But neither the historian nor the philosopher has her own sense of the modal structure of reality challenged by the historical figure. In the second half of this essay, I explore what such challenges might look like, were they taken seriously, say, via a renewed commitment to 're-enactment' as a humanistic methodology. I focus especially on the case of the $13^{\text {th }}$ century Franciscan friar, Roger Bacon, who has been alternatively seen as a mad medieval or a proto-modernist. To give Bacon full voice would involve setting aside these two stereotypes in favour of taking the future that he envisaged as a normative benchmark for judging our own world.

\section{Science as the Fine Art of Making Up the World as One Goes Along}

It has become customary to characterize the relationship among the three main disciplines that constitute science and technology studies (STS) - history, philosophy, and sociology of science -- as follows: History supplies the raw material that is initially understood in terms of sociological categories, which philosophers then 'justify' in the relatively limited sense of offering a recurrent rationale that the historical agents could accept as their own (Fuller 2006: chap. 3). Daston and Galison (2007) exemplifies the sort of work that results from this process. The book collects a variety of scientific practices over the past three centuries, organizes them according to disciplines and traditions, from which specific conceptions of 'objectivity' (e.g. correspondence, independence, etc.) are then teased out. There is no attempt to provide a grand philosophical - or, for that matter, sociological - narrative that supervenes on the history. Rather, philosophy and sociology are deployed simply to find interesting patterns in the historical detail. Sometimes this approach is presented as a revival of Neo-Kantianism because it appears to presume a correspondence 
between the organization of academic disciplines and the structure of domains of reality (cf. Fuller 2007: chap. 2).

My own version of social epistemology construes the tri-disciplinary relationship rather differently, but in a way that can also be explicated in Kantian terms. Consider the organization of Kant's Critique of Pure Reason. Here the human subject is cast as an epistemic speculator who is less concerned with insuring what she already thinks she knows than leveraging it into higher-order modes of cognition, ideally to achieve universal knowledge. This was certainly how Kant's immediate idealist successors (Fichte, Schelling, Hegel) read him, which in turn inspired them to develop philosophies that systematised all knowledge into curricula designed to empower free persons. One might then think of history, sociology and philosophy as corresponding, respectively, to the three levels of Kant's architectonic of mind: the manifold of experience, the categories of understanding, and the regulative ideas of reason. In contrast to Daston and Galison (2007), for whom the objects of history are 'determined' by being captured in discrete kinds that are both sociologically salient and philosophically meaningful for the contexts in which they normally appear, the idealists saw history itself as increasingly 'determined' in the sense that objects with distinct historical origins are consolidated into principles of increased scope that then enable access to new domains of objects. 'Science' is thus not a property of particular disciplines but rather a form of knowledge that emerges through what Kant's first major English follower, William Whewell, called the 'consilience' of different knowledge bases, with the ultimate aim of knowledge of all things for all people.

A feature of this idealist reading of Kant, which I also endorse, is its 'dialectical' character, such that as science opens up new cognitive horizons, it also reconstitutes its understanding of how it got to be where it is. Science is not simply about the growth of knowledge and/or power but equally about the periodic recalibration of the standards by which that growth is measured. This thesis is naturally read as a radical form of social constructivism, and it corresponds to the 'Orwellian' function of Whig history in Kuhn's understanding of scientific pedagogy (Fuller 2000: introduction). The difference between Kuhn's and my own take on Whig history is that I see it less as a 'noble lie' that scientists need to motivate themselves and a potentially sceptical public than as a publicly owned narrative whose collective contested performance defines the sense in which both scientists and lay people live in a common world. (Kuhn, for his part, is happy to have scientists and historians of science live in separate worlds, each left to their own historiography.)

To be sure, the very idea that social construction might extend backward as well as forward - that we might 'change the past' -- easily offends epistemological sensibilities, as Bruno Latour learned when he took symmetrical changes in time to be a consequence of the claim that microbes did not exist before Pasteur. In effect, Latour wanted to argue that over time Pasteur not only cleared the way for today's understanding of the nature of disease, but also successfully backdated the historical record, as Winston Smith was employed to do in 1984's Ministry of Truth, to make it so that microbes have always existed (Latour 1999: chap. 5). At first glance, to call this 'changing the past' may seem to be an imprecise way to talk about the striking but not so unusual fact that we could come to know that people in the past radically misunderstood important features of their own world (Hacking 1995: chap. 17). Without denying the truth in this observation, nevertheless the emphasis that Latour 
places on the ongoing nature of the backdating task is striking. When he refers to Pasteur's success in terms just as triumphalist as those of any Whig historian, he is not talking about the enduring truths that were revealed by Pasteur's discoveries but the tremendous amount of work across societies around the world that has been unleashed as a result of those discoveries. On this basis, Latour has provocatively argued that science is the most effective form of politics, if only because scientific discoveries serve as market signals or strong attractors in terms of which many others reorient their activities with the minimal application of external force (cf. Fuller 2007: chap. $3)$.

When students of post-Einstein physics want to do a reality check on ordinary usage, they observe that one can only change the present, not the past $o r$ the future. The statement shocks only because by 'the present' the post-Einsteinian incorporates much of what is ordinarily counted as the past and the future. Specifically, 'the present' is not simply the 'point in time' that the speaker happens to inhabit but a possibility space that extends both backward and forward in time and serves to stabilise the identity of the present as 'contemporaneous'. To register a change in how things are 'now' is ipso facto to alter how things could be, where 'could' is a measure of 'feasibility' in the broad sense, that is, how things might have got to be where they are now and, in light of that, how they might go in the future.

For example, our sense of the present involves the recognition both that Kant died more than 200 years ago and that his ideas remain - and are likely to remain -- an important voice in philosophical discourse. Were we to deny Kant's status as a virtual contemporary in this way, we would be effectively living in a different world, one whose past, present and future is bounded differently. In other words, our sense of Kant's continuing contemporaneity presupposes that the dates of his life (1724-1804) are an irrelevance: Kant might as well be living now, as far as our treatment of him is concerned. This is striking, since we routinely discount people by declaring them to be mere 'products of their time', by which we mean that their ideas lived and died with their bodies. In contrast, we treat Kant as (if he were) capable of resurrection because his ideas live on in us. Of course, at some point Kant may come to be seen exclusively as a product of his time, in which case our sense of the present will have changed substantially.

However, Latour's Pasteur example reminds us that a change of this sort would be no mere exercise in word magic. Given Latour's own self-understanding as an empirical investigator with no normative agenda, it is left to me to recast the Pasteur case as embodying a two-pronged strategy for world-changing:

(1) that any claim to have changed the present - as in the case of Pasteur -should be understood more as a promissory note that is being paid off at a variable rate than a fait accompli. In that case, the usual way of telling the history of science misleads by giving too much credit to the work of the originator and not enough to those who pave the ways leading both to and from the work;

(2) that changing the present is tantamount to changing the modal structure of history. I have likened this task to history's 'time-travelling' function, in which world-historic discoveries such as Pasteur's systematically re-wire the inferences drawn from evidence, so as to alter our sense of what is plausible and hence 'realistic' (Fuller 2010a). The extent to which we live in the same 
world is a function of the overlap in our modal judgements. Thus, insofar as people continue to differ about the role of microbes in the cause and spread of disease, the Pasteurian revolution remains unfinished, or more precisely, subject to 'uneven development'.

I differ from Latour in stressing the normative character of such re-wirings of history. Latour often writes as if history properly told would simply enumerate the entities added to the world, a position he once dubbed 'irreductionism' (Latour 1988). Thus, Pasteur first introduces microbes in late $19^{\text {th }}$ century France, and then his followers need to insert them backwards and forwards in history. In contrast, I take more of a balance sheet approach, whereby each entity added incurs costs, as the properties of already acknowledged entities need to be redistributed, resulting in some ontological restriction, if not outright elimination (Fuller 2007: chap. 3). This is in line with what Imre Lakatos (1981) called 'Kuhn Loss', namely, that the introduction of new entities in the wake of a scientific revolution invariably undermines the plausibility of some of the most distinctive entities posited by the previous paradigm by depriving them of a semantic role in the dominant causal narrative -- case in point: aether, in the wake of Einstein's revolution in physics. At best, they become fictions, derivatives of the real. Thus, angels have not been erased from historical memory entirely but shunted into a theological ghetto that requires some other entity (e.g. a textual or a neural trace) for their realization, since they now lack a free-standing existence. In effect, I treat ontology as a species of political economy, whereby 'reality' consists in living on a budget that requires tradeoffs between various possible entities (and their associated expertises), none of which can be fully realized if, as Latour wishes, they would all be realized to some extent (Fuller and Collier 2004: Postscript).

A host of metaphysical queries may be raised about the nature of this 'ontological budget' that cannot be dealt with here. But suffice it to say, the modal character of reality presupposes that we are normally oriented to such a budget, which is captured by the idea that not everything is possible at a given time and place. What is possible, under which conditions (which is to say, at what cost to whom and to what benefits and harms), constitutes the modal structure of the causal order. This issue is of special relevance to the history of science due to philosophical claims concerning science as a universal form of knowledge. Is science a robust form of inquiry that could be independently invented under various conditions, or a relatively unique approach to the world that leads a rather precarious existence? Here our counterfactual intuitions pull in opposing directions: on the one hand, science could emerge even were the world radically different; on the other, even a relatively slight change to the world would eliminate science altogether.

In Fuller (2008b), I cast this distinction in terms that figure in the rest of this essay -between overdetermination and underdetermination in history. Roughly put, the former captures a sense of historical necessity that overcomes events and the latter a radical contingency that succumbs to events. It is worth stressing that the same historical evidence can be used to support both alternatives. The two positions part company over how this common evidence base - for our purposes, the actual history of science -- is integrated with other evidence that is used to establish what has been and will be possible. This integration task, in turn, has a strong normative dimension that is bound to be controversial because of its potential policy implications. For example, by the logic of underdetermination, insofar as we continue to value science 
as it is done, and we trace it to events that are considered 'accidents of' or 'unique to' European history, we are providing prima facie grounds for a certain kind of cultural imperialism. In effect, we are claiming that science requires a rather specific cultural support system that needs to be artificially maintained in order to realize its universal aspirations. These claims would be more openly discussed - and contested - if what in the next section I call a cordon sanitaire did not exist between the history and philosophy of science, which involves not only turning the two counterfactual intuitions into default disciplinary postures (i.e. historians as underdeterminationists and philosophers as overdeterminationists) but also dividing the labour between the two disciplines in terms of temporal horizons (i.e. historians as facing backward and philosophers as facing forward from the present).

\section{Removing the Fence that Makes Historians and Philosophers of Science Such Good Neighbours: Start by Imagining the World without Us}

In my philosophical youth, at the height of the Cold War, I was very much taken by two contrasting images of the post-apocalyptic epistemic world: an optimistic and a pessimistic one. The former, courtesy of Karl Popper (1972), imagined that a new intelligent species could re-create our civilisation by accessing the 'objective knowledge' contained in our libraries and databases after what presumably would have been neutron bomb-based holocaust. The latter, due to Alasdair MacIntyre (1981), envisaged that such efforts would be more like those of today's archaeologists, who, even were they blessed with a complete set of our texts and artefacts, would still struggle to understand the sorts of lives we led in virtue of possessing these things. I originally cast the distinction as being about the metaphysical make-up of a world in which knowledge is possible (Fuller 1988: 51-2), but the following will re-cast it as a difference in historiographical sensibility.

Despite the futuristic if not science-fictional character of their thought experiments, Popper and MacIntyre were clearly trying to make philosophical points about our own world. On the one hand, Popper wanted to show that knowledge has much less to do with our personal make-up - either mental or physical - than epistemologists have normally supposed; hence, the autonomy of objective knowledge as 'world 3', as opposed to the 'world 1' of matter and the 'world 2' of belief. On the other hand, MacIntyre wanted to show that knowledge is so closely tied to particular practices that, in the absence of the skills, dispositions, sites and occasions for enacting those practices, texts and artefacts are no more than prosthetic corpses. While Popper's thought-experiment was meant to justify the existence of 'science' as a distinct form of knowledge (albeit as a spin-off of all manner of interested, biased and error-prone modes of inquiry), MacIntyre's was meant to undermine the existence of analytic moral philosophy (aka metaethics) for having lost touch with the ways of life that gave meaning to the words that now glibly tumble from philosophically trained mouths.

In terms of the alternative philosophies of history counterposed in Karl Mannheim's (1936) classic Ideology and Utopia, Popper (perhaps against type) appears to be a radical utopian, who sees a tomorrow that manages to retain everything good from today (i.e. the libraries and databases), whatever else it may contain (e.g. a different species of knowers), while MacIntyre is the reactionary ideologue who downgrades 
the present for its failure to reproduce essential features of past modes of existence in its own practices. Although Mannheim was concerned mainly to provide a genealogy of the bipolar political world-views of 'left' and 'right' that emerged in the $19^{\text {th }}$ century and continued to structure $20^{\text {th }}$ century debate, he acknowledged its roots in the ongoing tensions between what Max Weber (1963) called, respectively, the 'prophetic' and 'priestly' modes of life in the Abrahamic religions. I am inclined to accept Mannheim's general orientation here. However, I would explain it in terms of a distinction between an over- and under-determinationist view of history (Fuller and Collier 2004: chap. 6). Thus, Popper (and the utopian/prophetic mode) represents an overdeterminationist and MacIntyre (and the ideological/priestly mode) an underdeterminationist approach to history.

Overdeterminationism captures a fundamental optimism in the robustness of history's trajectory, such that the actual details of the past could be radically altered and most of what we already value would remain, or at least be available on tap. This is certainly the spirit in which to understand the 'rational reconstruction' approach to the history of science recommended by Popper's follower, Lakatos (1981), who was comfortable both affirming a belief in scientific progress and denouncing most of the actual history of science. After all, to say that something could have been done more efficiently is not to deny that it has been done. In contrast, underdeterminationism reflects, if not outright pessimism, at least concern for the precariousness of all that we have accomplished, which requires sensitivity to and respect for our mutual dependence as the key to the continued survival of what humanity values. MacIntyre's subsequent career certainly embodies this sensibility (e.g. MacIntyre 1999), in which he has been joined by more postmodern theorists who stress the 'immanent' over the 'transcendent' character of the human condition (e.g. Butler 2004).

My own considered view is that underdeterminationism - especially of the MacIntyre variety - dwells on the most self-debasing features of humanity's divine heritage, namely, our proneness to a state of 'nonage', to recall Kant's disparaging characterisation of those whose understanding of humanity was based on a pre-critical reading of the Bible, one that left the impression that we are the children of God who never manage to grow up. Here I prefer Kant's rather literal and uplifting understanding of our divine heritage that was indicative of Enlightenment anticlericalism - that is, as beings created in the image and likeness of the deity, once we become adults, we take full responsibility for our actions without necessarily disowning our parentage (Fuller 2008a: chap. 7). Indeed, we act godlike in our own way, which for Kant amounted to inscribing a 'view from nowhere' in his approach to both theoretical and practical reason.

Of special relevance here is the human significance that Kant assigned to a discipline that he believed had failed on its own terms to render God intelligible: theodicy, the justification of the world's many specific imperfections as design features of its being the overall best possible world. Kant (along with many of the devout, I should add) found it blasphemous that theologians would try to minimize human suffering by claiming to speak on God's behalf in this way. Nevertheless, theodicy provides the clearest precedent for our valuing all errors -- even evils -- as learning experiences en route to a just world order, a thesis that Kant developed in his 1784 essay, 'Idea for a Universal History with a Cosmopolitan Purpose' (Neiman 2002: chap. 1). Historical 
moments of suffering correspond to aspects of nature that, albeit suboptimal in their own right, somehow serve God's global optimisation strategy. Epistemic progress may be thought about in a similar fashion - namely, as humanity's temporal experience of God's timeless creation, a modern update of the medieval distinction of ordo cognoscendi and ordo essendi: What we know historically, God wills timelessly. The human quest for knowledge is therefore cast as a journey to an always already settled place, the 'Mind of God'. This phrase was first popularised by Aquinas' main contemporary rival, Bonaventure, who penned The Mind's Journey to God, a proposed curriculum for the University of Paris that anticipates late Enlightenment conceptions of history as humanity's collective self-education (Fuller 2010b: chap. 8).

Popper's overdeterminationism clearly partook of Kant's peculiar strand of optimism, whereby from the ashes of theodicy emerged the modern faith in progress. It testifies to science's ultimate other-worldliness, its providential perseverance in the face of seemingly interminable resistance - not only from error and evil but also from such mundane ways of knowing as prejudice and common sense (Passmore 1970: chap. 11). However, its full realization requires the removal of the cordon sanitaire that normally exists between historians and philosophers of science, whereby both disciplines agree to the principle that 'the past is a foreign country', separated in time as if by space - a poetic definition of Kuhnian 'incommensurability', if there ever was one. The cordon sanitaire allows both for historians to argue that past figures held beliefs suited to their times and for philosophers to argue that those same figures would adopt our beliefs, were they transported to our times. In that case, there is no reason for the present to learn from the past or the past to be humbled by the present. Moreover, historians and philosophers can interpret this state of mutual noninterference (aka tolerance) to their own respective epistemic advantage. What the historian raises to the level of incommensurable world-views, the philosopher treats as remediable error. If the philosopher demotes the historian's knowledge claim to a quaint piece of trivia, the historian can repay the compliment by accepting the philosopher's claim as an innocuous fancy.

Historians and philosophers enforce the cordon sanitaire denying figures from the past a full voice in their own inquiries. What I mean by a 'full voice' will be made clearer in the second half of this paper. But as a first approximation, it involves taking seriously that figures from the past intended their thoughts and actions to have purchase not only in their own lives and those of their contemporaries but ours as well. As it stands, both historians and philosophers treat past figures as polite witnesses, resulting in what I originally called, with regard to Kuhn's (1970) historiography of science, a 'double truth' doctrine - one for historians and one for scientists (Fuller 2000: chap. 1). Put provocatively, historians and philosophers can treat themselves as ultimate truth-tellers and each other as purveyors of fiction or incidentals, just as long as the figures from the past common to their narratives are themselves only semi-realized. But once we insist on a more fully developed sense of the past figures that interest us, then the cordon sanitaire proves difficult to maintain - indeed, perhaps to such an extent that, depending on where our normative allegiances ultimately lie, we may need to radically revise either our disciplinary boundaries or our attitude to the past figures in question. In any case, the distinction between 'the past' and 'the present' becomes problematic. 
Behind this point is the claim that the past is not simply something to be handled in some normatively pre-approved fashion - say, through the application of the relevant historical or philosophical methods -- but is itself constitutive of that normative sensibility. We may be used to saying that the cut between what counts as 'the past' and 'the present' is relative to the inquirer's interests, but we rarely acknowledge that those past denizens under study would-might balk at any such cuts, preferring instead to be treated as our contemporaries, even if it ends up that they provethey prove to be hostile witnesses in our inquiries. Thus, in the case of the historian, it is not enough for us to understand past figures: However well we might do that, it would seem pointless if these figures did not also understand us as meaningfully related to them, such that (at least) they see why we might find them interesting, even if they would not fully accept our interpretation of their ways. Similarly, for the philosopher, it is not enough for past figures to see the errors of their ways: They should also appreciate that we have been trying to make good on what they were trying to do. Only then would the corrections strike our visitors as more than glorified copy-editing of their original texts but an outright epistemic improvement on their original projects.

Bluntly put, my proposal is that, as either historians or philosophers, we need to learn to treat denizens of the past as our contemporaries. This involves adopting a state of mind that in principle enables the past to change our present-day minds in ways sufficiently fundamental to renegotiate our relationship to the past, perhaps extending to the reconceptualisation of our own projects. This amounts to pushing the idea of 're-enacting the past' as far as it can go. Here it is worth recalling that, when first advanced by Wilhelm Dilthey as part of a 'critique of historical reason' at the end of the $19^{\text {th }}$ century, 're-enactment' foundered because the simple assertion of humanity's species unity was insufficient to underwrite a reliable method (Harrington 2001). However, Dilthey's proposal is set to travel much further in the future, by virtue of two developments:

(1) Increasing advances in neuroscience and their integration with historiography will provide a more finely grained sense of how exposure to particular foods and drugs, as well as people, places and artefacts, shaped the past's 'psychotropic' environment. Even if neuroscience is never capable of identifying the occurrence of particular thoughts in the past, it may still give us access to the cognitive mood of the past, that is, the 'spirit' or 'mindscape' within which our forebears thought (Smail 2007).

(2) Advances in virtual reality technologies will enable the psychotropically enhanced humanist to conduct the re-enactment in the presence of simulated versions of the relevant past figures and conditions ('Second Life' style) alongside the surviving cultural artefacts that provide the usual touchstones for humanistic inquiry. The verisimilitude of this endeavour may be enhanced by the hypothesised capacity of the brain to 'mirror' the experience of an action simply by observing it (Turner 2007).

Taken together, (1) and (2) are likely to elevate the pursuit of 'historical re-enactment' above armchair speculation, amateur recreation (e.g. staging past battles), or at best the sort of archaeological reconstruction on which the main Anglophone defence of re-enactment -- Robin Collingwood's - was grounded. Instead it would become a generalised method of inquiry, for which humanist scholars might routinely seek grants to take the time to live lives like those they wish to understand, during which they would undergo strictures not unlike those of method acting (McCalman and Pickering 2010). 


\section{Letting the Past Talk Back: The Ultimate Test of 'Giving Voice'}

Setting to one side whether the historiographical imagination is likely to be prosthetically enhanced in the near future, conceptual objections remain to the proposal that we engage in a mutual recognition exercise with denizens of the past. At the very least, the historian or philosopher who allows figures from the past to talk back is setting herself up for a fight - not least over whether her own latter-day inquiries are properly conceived. But if historians already imagine themselves visiting past figures and philosophers transporting past figures to their seminars, then what principle stops us from fleshing out those counterfactual interactions into give-andtake social interactions based on jointly negotiated epistemic standards, which in turn might range over both the ends and the means of what we jointly agree to be 'knowledge'? After all, when we call ourselves 'Darwinian' or, for that matter, 'Christian', we are presumably not merely taking advantage of the fact that Darwin or Jesus is dead and hence cannot stop us for appropriating his name for our purposes. Rather, we imagine that he would endorse our activities done under his name by virtue of recognising us as amongst his legitimate heirs. In that respect, we implicitly invite time-travelling normative judgment, which once subject to a comprehensive historical re-enactment may of course result in disappointment.

In particular, we tend to assume that those in the past who defended theories and practices that we now regard as precursors to our own forms of knowledge would have also defended most, if not all, of the subsequent developments that increased the likelihood that things would turn out as they have. Yet, this assumption is far from obvious and likely to be false in many cases that are important for historically legitimising contemporary science. For example, we continue to support Newtonian science in spite -- not because -- of its theological foundations, yet Newton would regard our efforts at interpretive charity (i.e. not holding his theology against his science) as condescension, if not an outright emasculation of his position (Fuller 2010b: chap. 2). Of course, the last 300 years of the history of science has not been entirely a story of increasing deviation from the Newtonian norm. Physics, though now diminished in socio-epistemic status from its $19^{\text {th }}$ and $20^{\text {th }}$ century heyday, still largely aims for the sort of empirically comprehensive and mathematically unified conception of nature that drove Newton's own inquiries. Indeed, even avowed atheists like Stephen Hawking cannot avoid Newton-inspired talk of 'entering the mind of God' to justify the increasingly esoteric speculations of cosmologists about the origins of the universe.

To be sure, Newton might have greater difficulty reconciling himself to the history of biology. He would be disappointed by the eventual acceptance of Darwin's theory of evolution by natural selection - even in the face of objections by Whewell, Herschel and Mill that Darwin had failed to render the unity of nature fully intelligible. Newton would see this as indicative of the deviant path that history has taken from the methodological example he laid down in Principia Mathematica. After all, the closer that human cognitive powers are seen to be to those of animals, as Darwin effectively urged, the more mysterious Newton's own 'view from nowhere' achievement becomes and the incentive to pursue it in the future diminishes. However, Newton would take heart at the influx of physics-minded scientists who, largely thanks to the 
Rockefeller Foundation, filled the ranks of $20^{\text {th }}$ century genetics and later molecular biology - along with the nearly science of 'biophysics' (Rasmussen 1997). Together these Darwin-neutral disciplines managed to reassert the mechanical world-view, most recently evidenced in the rise of 'biotechnology'. To be sure, all along their practitioners have had contend with Kant's rhetorical interference, which for the past two centuries has driven a wedge between mechanism and teleology, to reassure first priests but more recently atheists that scientists are not literally in the business of second-guessing God's motives.

However, a time-travelling Darwin would have his own problems with the present. He would wonder why his name should continue to be attached to developments that so resolutely defy his own de-deified view of humanity, which he expressed in his lifetime as a general pessimism about our ability to take control of the deepest forces in nature, not least (as his cousin Francis Galton had proposed) through eugenics, the politically incorrect precursor of biotechnology. In this respect, Darwin might wish to dissociate himself from any of today's 'Neo-Darwinian' projects that suggest that we can alter substantially the course of evolution. But of course, on the other hand, he might come to be sufficiently impressed by the biomedical advances made over the past century to conclude that he had radically overstated the 'blindness' of natural selection and the 'mereness' of its metaphorical basis in artificial selection (Fuller 2008a: chap. 2). Indeed, Darwin may come to believe that his $19^{\text {th }}$ century critics were right, after all: A stronger case for the intelligibility of nature could be made than he originally thought. But such a concession to today's science would provide only superficial comfort to our own contemporaries, since it leaves Darwin closer in spirit to intelligent design theorists, the scientific creationists who make much of the information-like character of the genome, something that was inconceivable to Darwin in his own day and was only fully fathomed in 1953 with the discovery of DNA's double helix structure (Meyer 2009).

The rhetorical quandaries in which a time-travelling Newton or Darwin would land his present-day hosts speak to the extent to which these great scientists must be understood as having held just the right combination of beliefs in order to provide legitimacy for the science we currently practice. At the same time, we have also seen that both Newton and Darwin could be persuaded to change their beliefs, perhaps quite fundamentally, in light of learning what has happened since they lived. That prospect is of potentially considerable normative interest, as it serves to re-negotiate the social contract with aspects of the past that we want to treat as our own. In that respect, it matters less what Newton or Darwin actually believed than what it would take for them to believe something else, especially something that brings them closer to our own beliefs. (Of course, in the spirit of dissolving the cordon sanitaire between history and philosophy, our time-travelling scientists may wish to persuade us that our supposed advances are wrong turns in disguise.) Here we might distinguish two general strategies: (1) Nudging: We can get them to our position as a natural extension of their own position, say, by showing them advances in research to which they themselves contributed directly. Philosophers tend to overestimate the utility of this strategy by assuming that because we recognise a scientist as our precursor, she would recognise us as her follower. (2) Incentivising: In cases where some of our own position is radically at odds with some of the past scientist's beliefs, we can try to persuade the scientist that our shared common ground is actually more important to maintain, which then provides a basis for having an interest in changing her mind. 


\section{Constructing an Alternative Future from the Past: Giving Roger Bacon Back His Voice}

A good way to understand my perspective on the philosophy of history is to see why I object so strongly to the following statement, which clearly expresses the postKuhnian, anti-Whig sentiment - what Fuller (2000) decried as a 'Priggish' attitude -towards the history of science that was prevalent in my graduate school days:

Roger Bacon has often been victimized by his friends, who have exaggerated and distorted his place in the history of mathematics. He has too often been viewed as the first, or one of the first, to grasp the possibilities and promote the cause of modern mathematical physics. Even those who have noticed that Bacon was more given to the praise than to the practice of mathematics have seen in his programmatic statements an anticipation of seventeenth-century achievements. But if we judge Bacon by twentieth-century criteria and pronounce him an anticipator of modern science, we will fail totally to understand his true contributions; for Bacon was not looking to the future, but responding to the past; he was grappling with ancient traditions and attempting to apply the truth thus gained to the needs of thirteenth-century Christendom. If we wish to understand Bacon, therefore, we must take a backward, rather than a forward, look; we must view him in relation to his predecessors and contemporaries rather than his successors; we must consider not his influence, but his sources and the use to which he put them (Lindberg 1982: 3).

The medieval historian David Lindberg is expressing what Harry Collins (1981) was then calling 'methodological relativism', which was being promoted as a renewed commitment to objectivity. In effect, it proposed to shift the epistemic focus of the historian's role from that of constituting the object of historical inquiry (as had been advanced by various Neo-Hegelian and hermeneutical approaches, as well as Whig histories) to that of providing a context for a sympathetic hearing of the original historical agents (on the model of social and cultural anthropologists). Whereas the former presented the historian as a fellow agent - if not the dominant one - in an ongoing dialogue with the past, the latter presented her as an eavesdropper or silent witness to conversations to which she was not meant to be party (cf. Fuller 1988: chap. 6).

At this point, I must observe that, whatever their merits, Lindberg's claims about how to study Bacon formed part of a historiographical dispute that has come to lose its salience in the intervening three decades. A good way to see this is that two theorists of history who we now often see as standing together, Hayden White and Thomas Kuhn, would have taken opposing sides on the matter that exercised Lindberg. White's stress on the narrative constitution of history - to such an extent that the historian is not unreasonably seen as making history her own - radicalises the subjective approach to the past that Lindberg opposed, whereas his own position corresponds to Kuhn's stress on the historian's ability to detach herself from presentday scientific concerns as propaedeutic to making sense of past scientists.

However, this debate over whether historical knowledge is, so to speak, subject- (e.g. White) or object- (e.g. Kuhn) led was displaced and the corresponding distinction 
blurred with the onset of postmodernism in the 1980s. ${ }^{1}$ These two now 'postmodern' positions were seen as united against a common - albeit probably mythical 'modernist' historiographical foe, namely, one based on a strong metaphysical realism modelled on classical physics consisting in 'facts of the matter' about the past regardless of what anyone in the past, present or future might think. Nobody interested in the practice of history enthusiastically embraced this position, since it appeared to imply a theory of causation that committed the historian to some odious form of determinism. But it did provide a new basis for re-drawing the lines between the 'human' and the 'natural' sciences - not to mention a renewed fashion for talking about 'ontology' more generally (e.g. Hacking 2002).

I wish to revisit the pre-postmodern disposition concerning the epistemology of history, taking the side of the subject-led approach. Consider the dreaded 'Whig history'. From the standpoint of the object-led history approach championed by Lindberg (and Kuhn), it constitutes the object of history incorrectly because it fails to respect the past in its 'pastness'. For these objectivists, 'the past is a foreign country' operates as a de facto demarcation criterion for what is eligible for historical investigation. Thus, despite holding a doctorate in contemporary physics, Kuhn made no historical inquiries into quantum mechanics or relativity theory after the 1920s because most of the paradigm-bounding issues that were open then remained open when he wrote. Implied here is that a proper object of historical inquiry requires a sense of conceptual and empirical closure that is recognized by the relevant community of inquirers. In sociological jargon, the distinction between past and present is a piece of 'disciplinary boundary maintenance' performed by historians that advocates of Whig history violate by treating the past as if it were the opening act for the present. Unsurprisingly, the ranks of Whig history are filled with professional scientists who are prone to interpret professional historians of science as somehow trying to render the past irrelevant to current practitioners, when in fact the past is a ready source of examples, albeit ones often teaching negative lessons.

Subject-led philosophers of history such as myself sympathize somewhat with the Whig historian's bewilderment. We too see continuity between the past and the present, and hence reject the very idea that 'the past is a foreign country'. However, the Whig sees the continuity going only one way: She projects a line back from the present to -- recalling Lindberg's example -- Roger Bacon. But of course, the line projected may go the other way, namely, from Roger Bacon to the future he would have liked to see realized. Indeed, we may decide that some version of Bacon's unrealized past future would have been preferable to the actual future for which the Whig wishes to provide historical legitimation. In any case, the subject-led philosopher of history does not presume the natural legitimacy of the present in dictating the terms for evaluating the past. Even Hegel, who is so often read as justifying the Prussian status quo, never proclaimed 'the end of history' -- though Nietzsche believed that a Hegelian would need to say that at some point in time. Rather, Hegel held that any successful practices in one's own day are ultimately means to still greater ends that in retrospect may provide a basis for ironic commentary on what had been truly achieved back then. In this respect, the Whig jumps the Hegelian gun, presuming that we are closer to the end of history than we probably are. (Francis Fukuyama, call home!)

${ }^{1}$ Funkenstein's Hegelian subject/object... 
Given this background, let us now return to the offending passage by Lindberg. The nature of the offense is captured in the question: If I were Roger Bacon, would I appreciate being given the Lindberg treatment? It is instructive that the figure in question is the mid- $13^{\text {th }}$ century Franciscan friar Roger Bacon - someone who very clearly believed that his theological, philosophical and scientific views would be vindicated in the fullness of time, a point that Lindberg, to his credit, does not hide. Nevertheless, Bacon would find Lindberg's overall portrayal of him invidious, since it reinforces what appears to have been a mid- $13^{\text {th }}$ century consensus that regarded Bacon's Platonically tinged declarations as relics of an approach to natural philosophy whose preoccupations with mathematics and astrology were rapidly being superseded by a generation influenced by the more earthbound concerns of the then-newly translated Aristotle. In other words, Bacon would regard Lindberg as reducing his thoughts and actions to the interpretive treatment they received at the hands of his contemporaries.

Lindberg could try to justify this treatment, as Quentin Skinner (1969) might, arguing à la Wittgenstein or Austin that simply by virtue of engaging in the language game of mid- $13^{\text {th }}$ century natural philosophy, Bacon implicitly agreed to have his speech and actions judged by the rules of that game as defined by recognisably competent players. Lindberg might regard this as a historiographical version of 'natural justice', as Bacon is judged by his peers (however harshly) rather than those in the future with whom he never had contact (however generously). But in Bacon's defense, it could be argued that Lindberg's specification of the historical context amounts to 'microWhiggery'. After all, Lindberg's evaluative standards, while no more, are also no less than those upheld by a consensus of Bacon's contemporaries. In effect, their utterances are presumed to be normal expressions of a shared cognitive competence, in terms of which Bacon's own utterances are then treated as deviations. However, this presumption relies on a retrospective sense of closure about the nature of Bacon's times as well as his own fate. Such closure is familiar from mid- $20^{\text {th }}$ century social anthropology, which justified the ethnographer's extended snapshot view of the tribe by claiming that, unlike 'modern' societies, the tribe's normative horizons are historically 'frozen'. This in turn conveniently circumscribed the object of inquiry so that the inquirer might reasonably master it without having to take any responsibility for it. When translated into historical practice, à la Skinner, a kind of collective intellectual obituary needs to be written to turn the past into a foreign country. But exactly how long after the original events should this mass death be declared and the coroner's report issued by the attending historian?

Lindberg's methodologically convenient answer is to judge Bacon by what those of his own and the next generation thought of what he said and did. In that case, to include others whose lives did not overlap with Bacon's would be to shift the context of judgment beyond what Bacon could have reasonably imagined. But is that really the case? I do not believe so. On the contrary, Lindberg radically foreshortens the temporal horizon of intentionality: In at least the Abrahamic world, beliefs and desires are not normally limited to what can be realized in one's lifetime but extend into the indefinite past and future. Thus, when Roger Bacon expressed the belief that the cosmos is constituted as a mathematical system unified under the metaphysics of light, he did not also believe that the truth or falsity of this belief applied only to his 
lifetime - let alone corresponded to the judgment of the leading thinkers of his day. (The same, of course, could also be said of his contemporaries.)

In this respect, Lindberg's single-minded quest to capture the first-order intentional states of mid- $13^{\text {th }}$ century Christian intellectuals serves to obscure their second-order attitudes toward those states. In effect, he renders them (with a nod to Harold Garfinkel) transcendental dopes - that is, only capable of generating thoughts designed for their immediate audience but not some larger yet to be determined audience who might be more receptive. Pace Lindberg, Bacon and his interlocutors did not think of themselves as inhabiting a spatio-temporal island of intellectual communication that is available for study as a set piece. Such is a guild conceit of the object-led historian, borrowed partly from anthropology but also, and importantly, from behaviorist psychology, which black-boxed if not outright denied the mind's time-spanning capacities (Fuller 1988: chap. 5). Unsurprisingly, Lindberg interprets Bacon's preoccupation with the impending apocalypse -- a commonplace among Franciscans who followed Joachim of Fiore in reading the Bible as providing a model for understanding secular time -- as sufficiently pathological to excuse the house arrest to which Bacon was subjected later in his life. However, this is to ignore that both Bacon and his antagonists were generally contesting the identity of the timeless truth. It was something that would only be revealed in the fullness of time, whether or not it conformed to Joachimite strictures - which, for the record, was not some passing monastic fancy but a red thread that runs through modern notions of progress, not least Hegel and Marx's dialectical conceptions of history (Löwith 1948: chap. 8;

| Passmore 1970: chap. 11).

Here one needs to ask why someone like Bacon would leave such a voluminous written legacy, if he thought he was merely fighting battles with his contemporaries. Surely, his time would have been better spent doing things that would have made a more direct impression on them, whether it involved face-to-face persuasion or public demonstrations of empirical discoveries. To be sure, from today's standpoint, it is difficult to establish that someone is a philosopher or scientist without access to a textual trace simply because writing is presumed to be the most reliable means of pinning down specific beliefs and their justification. But this guild convention of the historian can too easily obscure the author's opportunity costs in having apportioned his life to the historian's convenience, especially given the improbability that Bacon would have anticipated the existence of someone like Lindberg.

This is not to say that a time-travelling Bacon would not be able to make sense of Lindberg's historiography. Rather, he would marvel at the prosaic status accorded to an epistemic standpoint that in his own day would have been explicitly associated with God's, as channelled through his angelic amanuenses. But in the next breath, Bacon would remind Lindberg that beyond the convenience that producing written works affords academic historians, it signifies his own desire for the intellectual contests of his lifetime to be carried forward, in which case the writings serve as potential scripts for extended improvised performances by future combatants. In this respect, Bacon's textual trace constitutes an act of self-positioning, such so that were he to reappear in our midst, he would be able to identify his descendants - and not simply rely on others to claim him as an ancestor. Moreover, Bacon would be hardly

${ }^{2}$ Funkenstein on the need to detach apocalypse from eschatology ( $\mathrm{PhD}$ on Lowith) 
idiosyncratic in trying to gamegaming the transcendent character of writing: JeanBaptiste Lamarck was another figure whose rhetorical strategy appeared to write off his contemporaries in favour of a more sympathetic future audience (Burkhardt 1970).

What makes my own anti-Lindberg position non-Whiggish is that I do not presume for a moment that Bacon would choose as his descendants those who claim him as a noble ancestor. Moreover, by reconstructing Bacon's position as a normative standard against which to judge the subsequent history of science - a feat tantamount to method-acting the role of Bacon for the contemporary stage - we have an opportunity to explore how, say, his commitment to the metaphysics of light might have got us quicker, say, to today's quantum information theory, not to mention other yet-to-bediscovered phenomena. Here Bacon would enjoy the advantage of being someone who held optics to be the foundational physical science, but without having been encumbered by the actual institutional history of science, not least one Isaac Newton, whose paradigm-defining work failed to account for nature of light to anyone's longterm satisfaction.

My historiographical proposal entails that we engage in 'rational reconstruction' of the past -- but in exactly the way that Imre Lakatos (1981) thought was not possible, namely, to project an alternative future from a discarded past. (Lakatos, in contrast, retrojected an alternative, cognitively streamlined past from the present as given.) I have called this approach retro-futurism (Fuller 2010b: chap. 9). It is clearly related to the 'alternate history' scenarios that populate the plots of science fiction. Therefore it should come as no surprise that the approach was originally championed by H.G. Wells in his failed bid to be appointed to the first chair in sociology at the London School of Economics (and the UK) in 1907 (Fuller 2011: chap. 1; cf. Lepenies 1988: chap. 5). Wells' definition of sociology as the 'science of utopias' does not seem so odd if we imagine, as Wells did, that the great $19^{\text {th }}$ century prototypes for sociology put forward by Comte, Marx and Spencer proposed various social innovations in order to draw alternative futures from inchoate tendencies in human history. While academic sociology ended up not rising to Wells' challenge, it remains a worthy one to which STS's radical constructivist take on the modal structure of historical reality naturally lends itself.

\section{REFERENCES}

Burkhardt, R. (1970).'Lamarck, Evolution, and the Politics of Science'. Journal of the History of Biology 3: 275-298.

Butler, J. (2004). Precarious Life. London: Verso.

Collins, H.M. (1981). 'Stages in the empirical programme of relativism'. Social

Studies of Science 11: 3-10.

Daston, L. and Galison, P. (2007). Objectivity. Cambridge MA: MIT Press.

Fuller, S. (1988). Social Epistemology. Bloomington IN: Indiana University Press.

Fuller, S. (2000). Thomas Kuhn: A Philosophical History for Our Times. Chicago:

University of Chicago Press.

Fuller, S. (2006). The Philosophy of Science and Technology Studies. London:

Routledge.

Fuller, S. (2007). New Frontiers in Science and Technology Studies. Oxford: Polity.

Fuller, S. (2008a). Dissent over Descent. Cambridge UK: Icon Books. 
Fuller, S. (2008b). 'The Normative Turn: Counterfactuals and a Philosophical Historiography of Science'. Isis 99: 576-584.

Fuller, S. (2010a). 'Freedom and Determinism in the $21^{\text {st }}$ Century: Prolegomena to the Rewriting of History' in Questioning Nineteenth-Century Assumptions about Knowledge, vol. 1, Determinism, ed. R.E. Lee. (Albany NY: SUNY Press), pp. 5-40. Fuller, S. (2010b). Science: The Art of Living. Durham UK: Acumen.

Fuller, S. (2011). Humanity 2.0: The Past, Present and Future of What It Means to Be Human. London: Palgrave Macmillan.

Fuller, S. and Collier, J. (2004). Philosophy, Rhetoric and the End of Knowledge (Orig. 1993 by Fuller). Hillsdale NJ: Lawrence Erlbaum Associates.

Hacking, I. (1995). Rewriting the Soul: Multiple Personality and the Sciences of Memory. Princeton: Princeton University Press.

Hacking, I. (2002). Historical Ontology. Cambridge MA: Harvard University Press. Harrington, A. (2001). 'Dilthey, Empathy and Verstehen'. European Journal of Social Theory 4: 311-29.

Kuhn, T.S. (1970). The Structure of Scientific Revolutions. $2^{\text {nd }}$ edn. (Orig. 1962). Chicago: University of Chicago Press.

Lakatos, I. (1981). 'History of Science and Its Rational Reconstructions'. In I. Hacking, ed., Scientific Revolutions. (Pp. 107-27). Oxford: Oxford University Press.

Latour, B. (1988). The Pasteurization of France. Cambridge MA: Harvard University Press

Latour, B. (1999). Pandora's Hope. Cambridge MA: Harvard University Press.

Lepenies, W. (1988). Between Literature and Science: the Rise of Sociology. Cambridge UK: Cambridge University Press.

Lindberg, D. (1982). 'On the Applicability of Mathematics to Nature: Roger Bacon and His Predecessors'. British Journal for the History of Science 15: 3-25. Löwith, K. (1948). Meaning in History. Chicago: University of Chicago Press. MacIntyre, A. (1981). After Virtue. South Bend IN: Notre Dame Press. MacIntyre, A. (1999). Dependent Rational Animals. La Salle IL: Open Court Press. Mannheim, K. (1936 [1929]). Ideology and Utopia. New York: Harcourt Brace and World.

McCalman, I. and Pickering, P., eds. (2010). Historical Re-enactment: From Realism to Affect. London: Palgrave Macmillan.

Meyer, S. (2009). Signature in the Cell. New York: HarperOne.

Neiman, S. (2002). Evil in Modern Thought. Princeton: Princeton University Press. Passmore, J. (1970). The Perfectibility of Man. London: Duckworth.

Popper, K. (1972). Objective Knowledge. Oxford: Oxford University Press.

Rasmussen, N. (1997). 'The Mid-century Biophysics Bubble: Hiroshima and the Biological Revolution in America, Revisited.' History of Science 35: 245-91.

Skinner, Q. (1969) 'Meaning and Understanding in the History of Ideas'. History and Theory 8 (1), 3-53.

Smail, D.L. (2007). Deep History and the Brain. Berkeley: University of California Press.

Turner, S. (2007). 'Social Theory as Cognitive Neuroscience'. European Journal of Social Theory 10: 357-74.

Weber, M. (1963 [1922]). The Sociology of Religion. Boston: Beacon Press. 